\title{
STRUCTURAL CHANGE AND LONG MEMORY IN THE DYNAMIC OF U.S. INFLATION PROCESS
}

\author{
Mustapha BELKHOUJA* $\quad$ Mohamed BOUTAHAR ${ }^{\dagger}$ \\ GREQAM, Université de la Méditerranée 2 Rue de la charité, 13002 Marseille, France.
}

January 27, 2010

\begin{abstract}
Résumé
Les phénomènes de mémoire longue et de changement de régime sont très intimement liés. Dans ce papier, nous considérons le problème de détection des dates de rupture artificielles dans le cas d'un processus générateur des données à mémoire longue. Dans ce but, nous estimons le nombre de ruptures en utilisant plusieurs techniques, à savoir, les critères d'information, le test de Bai et Perron (1998) et la méthode de Lavielle (2004). Grâce à des expériences de Monte Carlo, nous examinons l'effet d'augmentation de la mémoire longue sur le choix du nombre de ruptures et leurs localisations, et nous montrons que la méthode de Lavielle est la meilleure technique vue que sa proportion de selection du vrai nombre de changements est la plus élevée particulièrement quand l'ordre d'intégration est proche de 0,5 . Comme il paraît que les taux d'inflation contiennent les phénomènes de mémoire longue et de changement structurel, une application sur le taux d'inflation américain est présentée afin d'illustrer l'utilité de ces procédures. Les résultats montrent qui la méthode de Lavielle (2004) choisit seulement deux ruptures, cependant, le nombre de ruptures détecté par les critères d'informations et la procédure séquentielle de Bai et Perron (1998) est supérieur ou égal à trois.
\end{abstract}

Mots clés: Econométrie, Modèles pour les assurances et les finances.

\begin{abstract}
Long range dependence and regime switching are very intimately related effects. In this paper we consider the problem of spuriously detecting break dates in hypothesis of long memory data generating processes. For this purpose, we address the issue of estimating the number of breaks using several techniques, namely, the information criteria, Bai and Perron's sequential selection procedure (1998), and the automatic procedure of Lavielle (2004). By means of Monte Carlo experiments, we investigate the effect of increasing the long memory parameter on selecting the number of breaks and their locations, and show that the Lavielle's method is the best technique since its frequency of choosing the true number of changes is the highest particularly when the order of integration is close to 0.5. As it seems that inflation rates contains long memory and structural breaks, an application to the U.S. inflation process is presented to illustrate the usefulness of these procedures. The results show that the Lavielle's method (2004) selects only two breaks, however, the number of breaks detected by the information criteria and the sequential procedure of Bai and Perron (1998) are superior or equal to three.
\end{abstract}

Key words: Econometrics, models for insurance and finance.

\footnotetext{
*E-mail: belkhouja_mustapha@yahoo.fr

†E-mail: boutahar@univmed.fr
} 


\section{References}

[1] Bai, J. (1997): "Estimation of a Change Point in Multiple Regression Models". The Review of Economics and Statistics, 79: 551-563.

[2] Bai, J. and P. Perron (1998): "Estimating and testing linear models with multiple structural changes". Econometrica, 66: 47-78.

[3] Bai, J. and P. Perron (2003): "Computation and analysis of multiple structural change models". Journal of Applied Econometrics, 18:1-22.

[4] Bellman, R. and R. Roth (1969): "Curve fitting by segmented straight lines". Journal of the American Statistical Association, 69: 1079-1084.

[5] Ben Aissa, S. and J. Jouini (2003): "Structural breaks in the US inflation process". Applied Economics Letters, 2003, 10: 633-636.

[6] Bhattacharya, P. K. (1994): "Some aspects of change-point analysis". Change Point Problems, IMS Lecture Notes Monograph Series, 23: 28-56.

[7] Boutahar, M. and J. Jouini (2003): "Structural breaks in the U.S. inflation process: a further investigation". Applied Economics Letters, 2003, 10: 985-98.

[8] Fisher, W.D. (1958): "On grouping for maximum homogeneity". Journal of the American Statistical Association, 77: 563-573.

[9] Geweke, J. and S. Porter-Hudak (1983): "The estimation and application of long memory time series models". Journal of Time Series Analysis, 4: 15-39.

[10] Guthery, S.B. (1974): "Partition regression". Journal of the American Statistical Association, 69: 99-126.

[11] Hawkins, D.M., (1977): "Testing a sequence of observations for a shift in location". Journal of the American Statistical Association, 72: 180- 186.

[12] Kwiatkowski D., Phillips. P., Schmidt P., Shin Y., (1992): "Testing the Null Hypothesis of stationarity Against the Alternative of a unit Root ". Journal of Econometrics, 54: 159-178.

[13] Lavielle, M. (2004): "Using penalized contrasts for the change-point problem". Elsevier.

[14] Liu, J., Wu, S., Zidek, J.V., (1997): "On segmented multivariate regressions". Statistica Sinica 7: 497-525.

[15] Phillips P. and Perron P. (1988): "Testing for a Unit Root in Time Series Regression". Biometrika, 75: 335-346.

[16] Said, E. S. and Dickey, A. D., (1984): "Testing for unit roots in autoregressive-moving average models of unknown order ". Biometrika, 71(3): 599-607.

[17] Schwarz, G. (1978): "Estimating the dimension of a model". Annals of Statistics, 6: 461-464.

[18] Sen, A., Srivastava, M.S., (1975a): "On tests for detecting change in mean". Annals of Statistics, 3: 96-103.

[19] Sen, A., Srivastava, M.S., (1975b): "Some one-sided tests for change in level". Technometrics, 17: 61-64.

[20] Yao, Y.C. (1988): "Estimating the number of break dates via schwarz's criteria". Statistics and Probability Letters, 6: 181-189.

[21] Yao, Y.C, and S. T. Au (1989): "Least squares estimations of a step function". Sankhya, Series. A, 51: 370-381.

[22] Yin, Y.Q., (1988): "Detection of the number, locations and magnitudes of jumps". Communications in Statistics. Stochastic Models 4: 445-455. 